\title{
The Open Innovation Model of Coaching Interaction in Organisations for Sustainable Performance within the Life Cycle
}

\author{
Angelina Roša (Rosha) *D and Natalja Lace \\ Faculty of Engineering Economics and Management, Riga Technical University, 6 Kalnciema Str., \\ LV-1048 Riga, Latvia; natalja.lace@rtu.lv \\ * Correspondence: angelina.rosa@rtu.lv; Tel.: +371-2910-3035
}

Received: 29 August 2018; Accepted: 27 September 2018; Published: 30 September 2018

check for updates

\begin{abstract}
Organizations need innovation to be competitive and sustainable on their marketplace. Sustainable performance is an important precondition for growth and development. In spite of a body of literature, non-financial factors of sustainable performance remain an open issue. Coaching has gained considerable attention in the business world for its impact on sustainable performance. The current research investigates the use of coaching interaction to facilitate organizational sustainable growth and development in the context of Miller and Friesen's five stage life-cycle model. The expert opinion survey is chosen as a central method of research. The questionnaire is developed on the literature review that is focused on the drivers for sustainable development throughout the life cycle, and the features of coaching that accelerate these driving forces. Fifteen experts took part in the survey conducted from November 2017 to January 2018. The results are estimated by considering the competence coefficient for each expert. The findings led to creation of an open innovation model, which displays relationships between the appropriate coaching forms and types and the organizational life cycle stages. The developed model enables choosing the optimal way of coaching delivery at any life cycle stage. This model is particularly valuable for the coaching support programs.
\end{abstract}

Keywords: sustainable performance; coaching; organizational life cycle; organization development; expert opinion survey

\section{Introduction}

In the 21st century, organizations respond to changing business environment, technological capabilities, and customer demand by providing a new approach to innovation, which is characterized by an open connection between technology and a market [1]. New open business models stipulate the growth and development of an open innovation economy. A new approach to innovation is based on the transfers across the boundaries of knowledge and technology [2]. Traditional integration model of innovation in which internally developed products are distributed through internal organizational channels is gradually substituted for the open innovation model in which both internal and external ideas are used to create value. The essence of the open innovation model is the allocation of the external flows of knowledge and distribution channels at the same level of importance as internal ones. External ideas and external ways to market are placed at the same level of importance as that assumed for internal ideas and internal distributed channels [3].

The connection between new ideas and economic outcomes is reflected in business models. An open business model is considered "a powerful organizational model of innovation" [4], which can lead to more sustainable development of organizations.

Sustainability is now a widely accepted concept in the field of research, and at the same time, sustainability is one of the important issues in business [5]. One of the most widely accepted definitions 
for sustainable development is coined by World Commission on Environment and Development (Brundtland Commission) [6] which states that, to make development sustainable means the ability of the present generation to meet the needs of the present without compromising the ability of future generations to meet their own needs" [6]. The concept of sustainable development has been recognized and placed on three pillars of development: economic, social, and environmental [7]. The concept of corporate sustainability derives from the broader concept of sustainability and it is regarded as a precondition for a favorable business growth and development $[8,9]$. Sustainable performance is regarded as the capability of the organization to meet stakeholder needs and expectations in a longer-term perspective by applying appropriate enhancements in management, organizational development, and innovation [10].

The aspects of sustainability are now under active consideration in the literature. The scientists study the issues of sustainable performance from different perspectives. Particular emphasis is placed on incorporation of sustainability considerations into project management, sustainable recourse allocation [11] and measuring sustainability [5,12]. New approaches are emerging to measure sustainable value while taking into account economic, social, environmental, and corporate governance perspective of sustainability [13].

Although a considerable amount of literature on sustainable development already exists, non-financial factors of sustainable performance still remain an open issue. Coaching has recently gained considerable attention in the business world for its impact on sustainable competitive advantage [14]. There are different ways to deliver coaching in organizations, such as individual coaching, executive coaching, team coaching, etc. The complex approach to coaching delivery in the form of the coaching program might be considered as the most effective. However, Bozer et al. [15] and Vidal-Salazar et al. [16] argue that the program can be deemed successful only when coaching outcomes are transformed into organizational change and sustainability. Hackman and Wageman [17] pointed to one more prerequisite for the efficiency of coaching to facilitate performance. They focus their research on team coaching and they argue that the impact of team coaching depends on competency as well as appropriate time and circumstances under which coaching is delivered. In line with Hackman and Wageman [17], the current study seeks to expand the scope and investigate the implementation of coaching interactions at organizational level in the context of organizational life cycle theory.

Scholars are unanimous in their view that awareness of the patterns of growth and the development of organizations contributes to better understanding of how organizations are created and sustained. Kazanijan and Drazin [18] argue that, if an organization uses the structure and processes that are tailored to the respective stage of development, the organization is most likely to grow and to achieve sustainable development faster than an organization that does not take into account the peculiarities of the stage the organization reaches. Coaching as facilitating practice might reinforce and support organization's capability to grow and develop in alignment with the life cycle stages.

Taking into account the fact that the patterns of development and coaching have a positive impact on sustainability, it was decided to develop the model of coaching interactions within the context of the organizational life cycle theory. The current research aims to investigate the appropriateness of different forms and types of coaching to facilitate organizational sustainable growth and development in the context of Miller and Friesen's five-stage model of the organizational life cycle [19]. The expert opinion survey has been chosen as a central method of research.

Therefore, the aim of this article is to propose the model of coaching interactions while taking into account the appropriateness of the forms and types of coaching in the light of the organizational life cycle theory.

In the first part of the article, an extensive literature review is provided. The literature review seeks to establish a theoretical framework to answer the following research questions:

What factors contribute to the sustainable development of organization throughout the life cycle? What features of coaching ensure the enhancement of the organizational driving forces? 
The findings of the literature review are used to prepare the questionnaire for the expert opinion survey. The second part of the article describes the methodology of the survey and it debates on the survey results. Finally, the model of the appropriate forms and types of coaching throughout the organizational life cycle is presented.

This study contributes to the literature by debating the impact of non-financial sustainability tools to strengthen organizational performance. By analyzing the effect of coaching on accelerating the driving forces for sustainable performance of organizations, the study investigates the interrelationship between the forms and types of coaching and the organizational life cycle stages. The findings of this study have practical implications for a wide range organization promoting coaching as facilitating activity to achieve sustainable performance.

\section{Driving Forces for the Organizational Life Cycle Stages}

The present article reviews the literature to identify the driving forces for the development of organizations in the context of Miller and Friesen's five-stage model of the organizational life cycle [19].

Miller and Friesen [19] argue that each stage differs from one another by internally consistent characteristics, among which, strategy, structure, and decision making. The period of time an organization stays at each stage can vary considerably. Hanks [20] endorses that view; he believes that each stage is characterized by a distinctive range of variables related to the organizational context, strategy and structure. Hanks [20] explains why organizations need change throughout their life cycle. "As organization grows in size and complexity, it reaches certain threshold points, where the existing configuration is no longer adequate and reconfiguration is necessary for the organization to continue to grow" [20].

Creativity is the organization's source to grow and develop at the Birth stage. Creative activities focusing on generation of new business ideas, designing products and technologies are crucial for an organization to start up [18]. However, creativity in itself is not enough without commercialization. Transferring business ideas and prototypes into viable products is a principal task during the first stage [20]. The attempt to find the appropriate market niche leads to an increase of the innovative activity [19]. "Since the firm is small and has no established reputation, it must avoid directly confronting its more powerful competitors. It does this by finding gaps or niches in the market which are not being filled, and it defends these niches by making extensive innovations" [19].

Besides creativity and innovativeness, market vision is regarded as the key skill the leader has to possess during the Birth stage [20]. Reid and Brentani [21] state that market vision and market visioning competence impact most significantly on the organization performance "particularly during the very early stages" [21]. At the Birth stage, the most crucial decisions are made based on entrepreneurial intuition of the organization founder [19]. Consequently, there is also a need to develop entrepreneurial skills, such as the ability to recognize market opportunities. Entrepreneurial leadership is a vital characteristic the start-up founder must possess [22].

The founders have to undertake substantial risks. The readiness to take the risk and a strong commitment to the business idea are the principal factors that ensure progress during the Birth stage [20].

At the Birth stage, the ownership is concentrated and the strategic and operating decisions are centralized in the organization $[19,20]$. To establish effective communication under the centralization of authority, the founder needs to acquire results orientation competency [20].

Therefore, encouraging creativity in the development of new products and technologies, fostering generation of innovative business ideas, improvement in communication, entrepreneurial intuition, and self-awareness are able to ensure sustainable growth and development of an organization during the Birth stage.

While an organization is growing, the complexity of organizational structure increases and new problems arise. Existing organizational structures and systems might be ineffective in addressing new challenges. The capability to produce in volume to expend the niche and meet the increased customers demand requires changes in all areas of the organization's activities. During this period, an organization undergoes constant change [18]. The changes in strategy, structure, situation, and 
decision-making imply a greater role for managers $[20,23]$. "Complex product strategies require more levels of managers to become involved in decision making" [19]. The Growth stage is characterized by increased autonomy at the lower-levels. Because of this process, the delegation of authority is adopted by organizations [19,24]. However, the delegation may cause problems. Greiner [24] notes that, on the one hand, top executives have trouble in giving up responsibilities because they are quite satisfied with the centralized directive leadership. On the other hand, lower management experiences problems in taking responsibility and making decisions. The nature of the decision-making process is changed toward "more analytical, more multiplex, and better integrated" [19]. The problems that are associated with the Growth stage are connected with obstacles in the process of change. Along with the demand to produce effectively with high quality and in value, there is a need to cope with people problems that are associated with high growth [18]. Hanks argues that "the organization must develop the ability to produce and distribute its products or services in volume to an increasingly diverse set of customers" [20].

Therefore, the challenges that are brought by a rapid growth might be overcome by the involvement of lower level management in decision-making process by means of effective delegation, and substitution of the flexibility in the structure, as well as disproportionate creativity by the functional structure and the team approach to management.

At the Maturity stage, the organizational structure and systems become more formal and hierarchical. Particular emphasis is laid upon profitability. "It is important to realize that unlike the conventional lifecycle concept the company is still growing in the maturity phase" [25]. Finding opportunities of change and maintaining, as well as improving growth capability, are the top challenges facing the leaders and management for sustainable growth [18]. However, despite the continuing growth, the development, including sales growth, becomes slower $[18,20,26]$. The organization becomes larger, more complex and adopts more formal bureaucratic structure [18-20,27]. Hanks [20] considers that a huge bureaucracy may cause the crisis at the end of the Maturity stage. The other reason of the crisis includes the loss of the ability to respond fast and effectively to changes in the business environment and market saturation. Hanks [20] sees the organization renewal, diversification, and decentralization as possible solutions to overcome the crisis. An organization typically reaches the Maturity stage in as little as ten years. By that time, the organization acquires a sufficient number of motivated and developed employees. Rutherford et al. [28] consider that the retention of key employees is a considerable challenge for the Maturity stage.

At the end of the Maturity stage, organizations have two ways of continuing the life cycle. The Maturity stage finalizes with two different options of transformation: the transfer to the next growth stage, Revival, or to the Decline stage [29,30].

Therefore, exploring the feasibility of growth to transform to the stage of growth not to decline, retaining a high sustainable performance of employees and coping with a bureaucratic structure might contribute to the further development.

In the Revival stage, an organization experiences rapid growth caused by diversification and expansion of product-market scope to reverse the stagnation of the Maturity stage [19,20]. Miller and Friesen [19] argue that the Revival stage is the most challenging and the most exciting stage of the five. An organization experiences significant changes in strategies, structure, and decision-making. The entry into turbulent new markets demands innovative high performance. Yusr [31] suggests that, when the companies seek to achieve competitive advantage though innovation, they need to make more efforts on building their innovation capability. Jung et al. [32] highlight the importance of both extrinsic motivation and intrinsic values for the innovative behavior.

Complex and heterogeneous environment requires change in the organizational structure. The functionally based structure is substituted by the divisional structure. As organizations become more decentralized and geographically dispersed, divisions gain considerable autonomy in operating decisions. Excessive autonomy may affect the communication between divisions, therefore integration is considered a key challenge an organization faces at the Revival stage [20]. 
Therefore, the challenges of the Revival stage might be overcome by attainment of autonomy of the divisions, high-level innovation and integration and effective communication between divisions.

In spite of empirical support, the Decline stage still is a subject of debate among scholars [23]. Lester et al. [23] explain this fact by the reluctance of managers and employees to see their organization in that light. Miller and Friesen [19] consider that ignoring the principles of growth, i.e., lack of well-defined strategy, failure to delegate, might bring an organization to decline.

Miller and Friesen [19] analyzed organizational performance during the Decline stage. They concluded that at the Decline stage, organizations unable to deal with a turbulent environment and external challenges. This situation is due principally to the lack of innovation and it leads to a focus on an internal power [19]. External threats and internal weaknesses are caused by the weakness of information processing mechanisms. On the one hand, organizations lack of information to analyses customers' needs and competitors' achievements. On the other hand, vertical and horizontal communication within an organization weakens and becomes ineffective. As a result, an organization the capability to respond properly to external and internal challenges [19].

Lester et al. [23] consider that decline does not mean the inevitable death of an organization. Fundamental change in the strategy, structure, decision making is vital to move to a more stable stage of growth [20].

Lester et al. highlight that an organization needs to make efforts to avoid decline "through the promotion and development of an innovative culture" [23]. However, despite the fact that innovations might improve the situation in the Decline stage, there is a lack of awareness, as well as a casual attitude towards the importance of innovations [30].

At the Decline stage, an organization operates in the environment in which the tolerance to failure is low [30]. This results in a decrease in risk-taking.

Therefore, the renewal of organizational strategy and structure, the development of innovativeness, the improvement of the information processing mechanisms, and the increase of the tolerance level are business tasks to overcome stagnation and to move to realignment.

The summary of the key driving forces that might contribute to the sustainable growth and development throughout the stages of organizational lifecycle and establish deterrence from decline is presented in Table 1.

Table 1. Key factors for the organization development throughout the life cycle stages.

\begin{tabular}{cc}
\hline Life Cycle Stages & Drivers for Organization Sustainable Development \\
\hline Creativity & Product and service innovations \\
Leaders self-awareness \\
Birth \\
Entrepreneurial intuition \\
Strategic vision \\
Intense commitment \\
Willingness to understand risk \\
Flexibility \\
Stage 2 & Involvement of lower level management in decision making \\
Growth & Effective delegation \\
& Team approach \\
& Capability to deal with almost constant state of change \\
Ability to manage high growth
\end{tabular}




\section{Coaching and Drivers for the Sustainable Development of Organizations}

Coaching is distinguished from a number of methods that facilitate organizational sustainable growth and development by its unique nature. Coaching is generally defined as a support practice aims to enhance learning and development, often within a context of change [33]. Coaching facilitates discovering opportunities and creating 'a culture of development' [34] to enhance performance and efficiency [35]. Definitions that are more recent consider coaching as a facilitating activity for self-directed learning and personal growth and change [36,37]. In coaching, the emphasis is made on providing space and resources to help people to consider their own issues and arrive at their own solutions [38]. Coaching is positioned as an activity where coach reflects on client's experience, wherein the client is an expert in the issue and he/she is a knowledge holder. The scholars and practitioners argue that coaching is beneficial for a person and for a client's organization, wherein achieving results and personal growth is considered as the key expected coaching outcome [39].

There are different approaches to classify coaching. Based on the literature review, the following categorization of coaching has been developed for the purposes of the present research (see Figure 1).

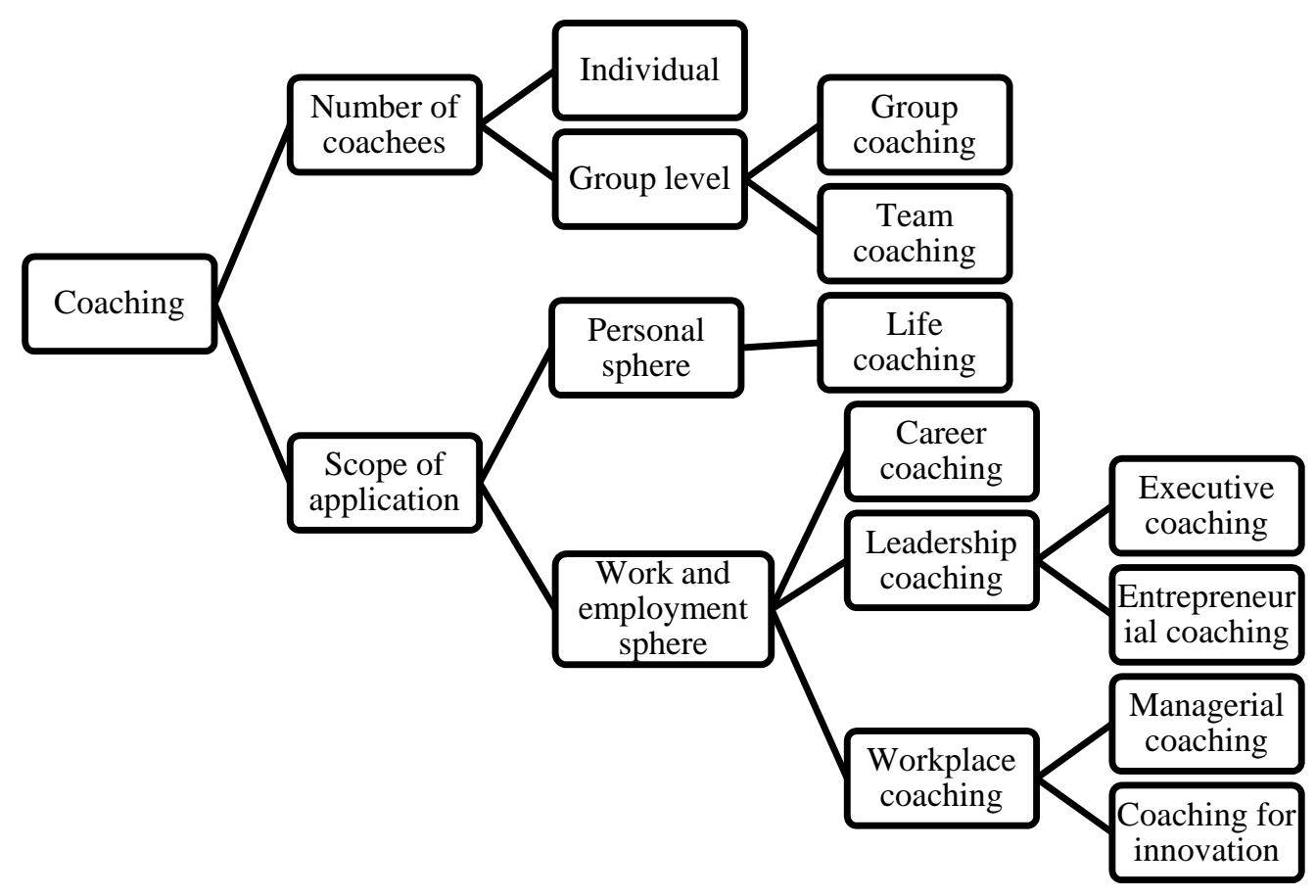

Figure 1. Categorization of coaching interactions.

Under this categorization, there are two forms of coaching: individual (one-to-one or dyadic) and group coaching. Individual coaching is delivered by a coach to a single individual, whereas group coaching is provided by a coach or coaches to a group of individuals. Such a group may embody individuals who share mutual goals and closely work together to achieve these goals, in this case, a group is called a team, and coaching that is delivered for this group is called team coaching.

There is considerable evidence to suggest that team coaching facilitates improving team capability to perform and achieve team results [40]. Rousseau et al. [40] claim that team coaching might improve innovation capabilities by encouraging the team members' innovative behavior. The study, which they conducted, aims to explore the relationship between team coaching and innovations in work teams. The results of the study show that team coaching is positively correlated with team innovation. "Unexpectedly, results revealed that team coaching may exercise a direct effect on support for innovation. This direct effect means that team leaders exhibiting coaching behaviors may encourage team members to engage in an innovation process of developing and implementing new ways of doing things" [40]. 
Rousseau et al. [40] explain how team coaching contributes to fostering innovation. When coaching is used as a leadership style for building and managing work teams, it is expected that the effectiveness of the teams will be enhanced through the changes in the behavior of team members. Team coaching facilitates matching expectations with opportunities as well as the comprehension of team strengths and weaknesses. Rousseau et al. [40] study shows that continual coaching interactions might provide motivational and behavioral change and thus enhance team innovation. Therefore, team coaching enhances the team environment, contributes to the development of team innovation capability, and hence creates a basis to attain sustainable performance.

Entrepreneurial coaching provides support and reinforces the independence of the founder by establishing the environment that triggers independence in solving every day and future problems. "Coaching, on the other hand, encourages entrepreneurs to put their own strategic vision into action" [41]. A distinctive feature of entrepreneurial coaching is its primary focus on the entrepreneur as an individual to facilitate founders in developing managerial skills and enhancing leadership capability [41].

Executive coaching, like other types of coaching, encourage behavior that promotes sustainable development and improve goals achievement, however, the primary focus of executive coaching is work-related sphere rather than personal life [42]. There is ample evidence that executive coaching provides support to people who have leadership and managerial responsibilities in organizations. "The presumed outcomes of executive coaching are changes in managerial behaviors with presumed increases in organizational effectiveness" [43]. As Grant [44] notes, executive coaching becomes particularly valuable in the period of constant organizational change. Executive coaching promotes the development of a readiness to embrace change, as well as contributes to the enhancement of leadership and managerial skills in the period of high growth, since executive coaching improve goal achievement and leadership self-efficacy [44]. The purpose of executive coaching is to achieve the desirable behavior change by means of raising self-awareness and learning, and thus to benefit both individual and organization $[45,46]$. Executive coaching supports in building strong commitment resulted in behavioral and attitudinal changes [46]. Meanwhile, de Meuse et al. [47] argue that executive coaching has a larger impact on organizational micro-level outcomes, i.e., behavior and performance, rather than on organizational macro-level outcomes, i.e., strategy. Therefore, executive coaching promotes and strengthens executive's capability to manage and lead an organization.

Managerial coaching encourages leading process and contributes to continuous improvement of employees' performance $[48,49]$. The peculiarity of managerial coaching is based on the fact that managers act as coaches for their subordinates. Developing subordinates' knowledge, skills, and abilities through coaching interactions provides improved, motivated, and effective performance. Managerial coaching might add value to increase organization's sustainability in the period of change by improving communication and accelerating integration [48]. Ellinger et al. [50] assert that managerial coaching positively correlates with employee performance and impacts favorably on employee commitment. However, Ellinger et al. [50] note that the effectiveness of managerial coaching depends, to a large extent, on taking into account the organizational and individual needs as well as the appropriateness of using this type of coaching. Therefore, managerial coaching facilitates learning and promotes internal communication and integration.

Innovation plays a crucial role in the development of organization [40]. Scholars consider that coaching may support innovation and sustain change by fostering development of innovation capability of organization [51].

\section{Materials and Methods}

For the purpose of the study, it was decided to apply a judgment-based method. Judgmental methods are used when appropriate information is not available for using statistical methods, ambiguity is high, or additional verification is required [52]. Expert judgment is a research method, which is widely used in management science, forecasting and statistics. 
The aim of the present expert opinion survey is to clarify the issue relevant to organizational sustainability. The survey seeks to gain the experts' view about the ways of utilizing coaching to accelerate and sustain organizational growth and development. Specifically, the experts are asked to rate the appropriateness of the certain forms and types of coaching to the organizational life cycle stages. Individual coaching, team coaching, executive coaching, entrepreneurial coaching, managerial coaching, coaching for innovation, and career coaching are analyzed in the context of Miller and Friesen's five-stage model of the organizational life cycle [19].

\subsection{Design of Expert Opinion Questionnaire}

The aim of the questionnaire is to gain the experts' view about the appropriateness of the use of certain forms and types of coaching to accelerate and sustain organizational growth and development. The questionnaire consists of two parts:

1. evaluation of the level of priority of the forms and types of coaching in the context of organizational life cycle;

2. expert self-evaluation.

The questions $1-5$ of the first part of the questionnaire are formulated in the same way. On a scale of 3 to 0 , with 3 being "high priority", 2 "middle high priority", 1 "low priority", and 0 "not applicable", the experts are asked to rate the appropriateness of the forms and types of coaching: individual coaching, team coaching, executive coaching, entrepreneurial coaching, managerial coaching, coaching for innovation, and career coaching, to the organizational life cycle stages: the Birth, the Growth, the Maturity, the Revival, and the Decline. Short descriptions of organizational life cycle stages, which were presented in the questionnaire in questions 1-5, are given below (see Table 2).

Table 2. Description of organizational life cycles.

\begin{tabular}{|c|c|}
\hline Stages & Description \\
\hline Birth & $\begin{array}{l}\text { Situation. The organization is small in terms of revenues and number of employees. } \\
\text { Strategy: niche strategy is a determine growth strategy. The strategic aim is to find the gaps in the market } \\
\text { and defense these niches by making extensive innovations. } \\
\text { Structure: simple formal organizational structure. Coordination among staff is weak since the internal } \\
\text { structure is simple and does not fully exist. } \\
\text { Decision-making: centralized decision-making. The main role in the development of organization belongs to } \\
\text { the founder/owner-manager. The owner-manager concentrates the power and makes the key decisions. } \\
\text { Decisions may conflict with each other because of the lack of detailed analysis and methodological } \\
\text { consideration of alternatives. } \\
\text { Key skills required. Success comes from creativity, flexibility, informality, commitment, and willingness to } \\
\text { undertake risk on the part of the founder. The founder must be result-oriented, creative and committed to } \\
\text { the business idea, and develop entrepreneurial skills such as the ability to recognize market opportunity. }\end{array}$ \\
\hline Growth & $\begin{array}{l}\text { Situation: organization is growing. The organization continues to meet growing demand for the products } \\
\text { and as a result, experiences continued growth in both sales and number of employees. } \\
\text { Strategy. Market segmentation becomes a determine growth strategy. Customers influence on decisions } \\
\text { most. The organization tries to identify specific subgroups of customers and to make small product or } \\
\text { service modifications in order to better serve them. The product line is broadening. } \\
\text { Structure: departmentalized functional structure. Functional departments are organized for the key areas of } \\
\text { business. Structure becomes more complex and less centralized. Managers are appointed to head } \\
\text { marketing, production and other departments. Greater effort is devoted to effective communication and } \\
\text { coordination among departments. Team approach to management prevails. } \\
\text { Decision-making. More levels of managers involve in decision-making, as a result, some authority is } \\
\text { delegated. However, power is still quite centralized. } \\
\text { Key skills required. While the successes in the Birth stage primarily depends on 'creativity, flexibility and } \\
\text { informality', to be successful in the Growth stage, the leaders need to learn to delegate effectively. }\end{array}$ \\
\hline
\end{tabular}


Table 2. Cont.

\begin{tabular}{|c|c|}
\hline Stages & Description \\
\hline Maturity & $\begin{array}{l}\text { Situation: sales levels stabilize. The focus turns from growth to profitability. Innovations switch from } \\
\text { product to process to improve production efficiency and reduce unit costs. The tendency is to follow the } \\
\text { competition and imitate innovations. Growth is occurring at a slower rate. A stable and circumscribed } \\
\text { product line is sold in traditional markets. The competition is going after the same group of customers. } \\
\text { Strategy: focused product-market scope. A short-term tactical rather than a long-term strategic orientation } \\
\text { prevails. There is also more attention paid to solving immediate problems and less emphasis given to } \\
\text { formulating explicit strategies. } \\
\text { Structure. Departmental, functionally based structure becomes more formal and bureaucratic. Information } \\
\text { processing activity changes: there are more emphasis upon formal cost controls, budgets, and performance } \\
\text { measures. There are typically several levels in the management hierarchy with a senior management team } \\
\text { at the top. } \\
\text { Decision-making. Conservatism becomes the norm. Style of decision-making is less innovative, less } \\
\text { proactive, less responsive and adaptive to the market. } \\
\text { Key skills required: to be effective, leaders must be proficient in formal planning, organization and } \\
\text { administration. }\end{array}$ \\
\hline Revival & $\begin{array}{l}\text { Situation. The organization experiences a period of rapid growth and reaches its largest size. This growth is } \\
\text { generated by major and minor product-line and service innovations, acquisition in different industries, } \\
\text { diversification and differentiation. Project teams and technical experts are recruited for R\&D, engineering } \\
\text { departments as well as to perform planning and analysis activities. Close attention is paid to project returns } \\
\text { and the evaluation of potential customer reactions. } \\
\text { Strategy: diversification, market segmentation, acquisition is determining growth strategies. } \\
\text { Structure. Divisional form of structure with autonomy of divisions and decentralization is adopted. } \\
\text { Decision-making. The heads of divisions become responsible for operational decisions and performance in } \\
\text { different markets. Highly sophisticated control systems to monitor the performance of the divisions are } \\
\text { used. While the divisions have the authority for the operational decisions, the power for overall strategy } \\
\text { making is still highly centralized. } \\
\text { Key skills required. A major challenge faced at this stage is integration to avoid over controlling the divisions } \\
\text { and at the same time, ensuring the synergy between divisions }\end{array}$ \\
\hline Decline & $\begin{array}{l}\text { Situation. Profitability drops because of the external challenges and because of the lack of innovation. The } \\
\text { product lines become still more outdated. The market scope is quite narrow. } \\
\text { Strategy. No particular strategy } \\
\text { Structure. The structure of organization is centralized with few control systems. } \\
\text { Decision-making. Few managers, who make a conservative, internally political approach, make most } \\
\text { decisions in the organization. Decision-making power is at the top of the organization; even routine } \\
\text { operating decisions are executed by higher level managers. Communications between hierarchical levels } \\
\text { and across departments are poor. } \\
\text { Key skill required. Renewal of organizational mission and strategy is to be a primary business task for } \\
\text { organization. Ignoring of renewal inevitably brings organization to continued decline and finally to the } \\
\text { death. }\end{array}$ \\
\hline
\end{tabular}

A file "Definitions of Coaching" was enclosed with the invitation letter and provided experts with working definitions of forms and types of coaching accepted for the present research. Working definitions are presented below in Table 3.

The second part of the questionnaire is intended to gather information about the level of competence of the experts (see Appendix A). 
Table 3. Working definitions of forms and types of coaching.

\begin{tabular}{cl}
\hline Forms and Types of Coaching & \multicolumn{1}{c}{ Working Definition } \\
\hline Individual Coaching & one-to-one or dyadic, is provided by a coach to a single client. \\
\hline Team Coaching & $\begin{array}{l}\text { differs from group coaching. Team coaching is collective engagement, a group of } \\
\text { people as a whole who performs to accomplish collective goals is considered a client }\end{array}$ \\
\hline Executive Coaching & $\begin{array}{l}\text { deals with individuals who have managerial responsibility. The purpose of executive } \\
\text { coaching is to enhance the client's professional performance and behavior change, } \\
\text { and thereby contribute to individual and organizational success }\end{array}$ \\
\hline Entrepreneurial Coaching & $\begin{array}{l}\text { is an individual support to entrepreneurs to facilitate developing entrepreneurial } \\
\text { self-efficacy and encourage entrepreneurs to transform their own strategic vision into } \\
\text { action }\end{array}$ \\
\hline Managerial Coaching (Manager as Coach) & $\begin{array}{l}\text { implies a supervisor or manager facilitating support to subordinates aims to improve } \\
\text { productivity and develop subordinates' professional skills }\end{array}$ \\
\hline Coaching for Innovation & $\begin{array}{l}\text { aims to drive innovative processes in organization from finding ideas and } \\
\text { developing them to linking innovations to the company's strategy by facilitating the } \\
\text { development and improvement skills contributing to innovation culture }\end{array}$ \\
\hline Career Coaching & $\begin{array}{l}\text { focused and goal-oriented type of coaching. The goal of career coaching is to assist } \\
\text { the client to develop a career path and achieve career goals }\end{array}$ \\
\hline
\end{tabular}

\subsection{Selection of Experts and Evaluation of the Level of Competence}

The following criteria are considered in the selection of experts: professional status, reputation, recognized competencies, academic degree, versatility, and objectivity. The optimal number of experts is still disputable question in the literature. The scholars consider that the number of experts depends on the nature of the problem and expected degree of uncertainty, while a larger group of experts may potentially provide more intellectual resources, the conflict of opinions and information overload may embarrass the elicitation. Therefore, to increase the accuracy of forecast, it was decided to compose the pool with fifteen experts whose knowledge and expertise complement each other and reflect the full scope of the subject matter.

The method of determining the competence of the experts is based on combination of different approaches:

1. competence coefficients $(k)$;

2. self-confidence evaluation; and,

3. documented method.

1. Competence coefficients $(k)$ are calculated from the processed results obtained from experts. The competence of the experts is estimated by the degree of consistency of experts' evaluation to the group evaluation. The coefficient is obtained by applying the following recursive formulae [53].

$$
\begin{gathered}
x_{i}^{t}=\sum_{j=1}^{m} x_{i j} k_{j}^{t-1} i=1,2, \ldots, n . \\
\lambda^{t}=\sum_{i=1}^{n} \sum_{j=1}^{m} x_{i j} x_{i}^{t}, t=1,2, \ldots, n . \\
\lambda^{t}=\sum_{i=1}^{n} \sum_{j=1}^{m} x_{i j} x_{i}^{t}, t=1,2, \ldots, n .
\end{gathered}
$$

where $j$ is the running number of experts; $i$ is the running number of questions; $m$ is the number of experts; $n$ is the number of questions; $t$ is the step of calculations; and, $x$ is the summarized responses.

Calculations start with $t=1$. The initial values of competency level are identical and equal to $k_{j}^{0}=\frac{1}{m}$.

2. Self-assessment method is used to measure the competence of experts. Self-confidence in theoretical knowledge, practical issues, and capability to forecast is determined for each expert. The coefficient ranges from 1 (or full competence) to 0 (or full incompetence). The experts are also asked 
to rate the level of their awareness of particular coaching types, with 10 being "perfect awareness" and 0 "absolute unfamiliarity". Self-confidence evaluation is calculated as the average score by using information that is obtained from the experts' responses to the questions 6 (Q6) and 7 (Q7) of the questionnaire.

3. Documented method evaluates the competence based on documentary sources, such as professional position, qualifications, and years of practice.

\section{Results and Discussion}

The expert opinion survey was conducted from November 2017 to January 2018. The list consists of 15 experts who have been individually invited to participate. It is expected that this study gives a general awareness in the tendency. The analysis of the experts' responses is made by summarizing expert opinions to derive an agreement among experts. Overall, the analysis is made in two dimensions. First, the most valuable types of coaching under each stage of organizational life cycle are extracted and analyzed. Second, the most valuable types of coaching across all the stages of organizational life cycle are identified.

Based on the questionnaire results and estimating the degree of consistency of experts' evaluation to the group evaluation, the competence coefficient $(k)$ was determined for each expert. The data for estimation of self-confidence in theoretical knowledge, practical experience, and capacity to foresee logical progression, as well as the awareness of particular coaching types, were obtained from the responses on questions $6(\mathrm{Q} 6)$ and $7(\mathrm{Q} 7)$ received from the experts. The results are calculated as the average scores.

Table 4 demonstrates the results of the analysis of the competence level of the experts, which comprise the competence coefficient, self-confidence average scores, and documented data for each expert.

The analysis of the competence of the experts reveals the following: fourteen experts have average and above the average values. One expert (11) has competence coefficient below the average and low score of self-confidence evaluation of the awareness for particular coaching types. Consequently, expert (11) is excluded from a list of experts and the expert's answers are rejected. The questionnaire answers on the appropriateness of the forms and types of coaching to the organizational life cycles are re-calculated while taking into account the competence coefficient for each expert, without taking into account the answers of expert (11).

Documented data analysis showed that two thirds of the experts are certified executive coaches having over five years of experience. $40 \%$ experts have the doctoral degree.

Consolidated results of the expert opinion survey that have been estimated by considering the competence coefficient for each expert, except expert 11, are presented in the Table 5 and are displayed on the diagram (Figure 2).

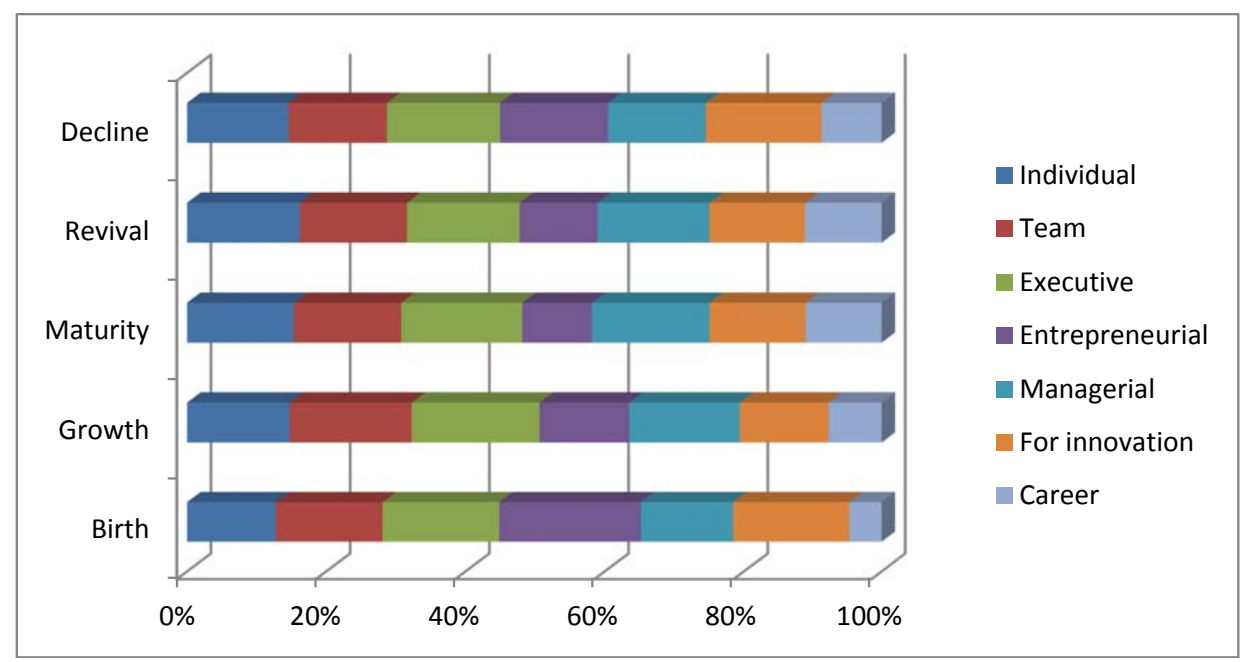

Figure 2. The use of coaching throughout the organizational life cycle (by experts' opinion). 
Table 4. Consolidated table of the experts' competence level.

\begin{tabular}{|c|c|c|c|c|c|c|}
\hline \multirow{2}{*}{$\begin{array}{l}\text { Expert's Running } \\
\text { Number }\end{array}$} & \multirow{2}{*}{$\begin{array}{l}\text { Competence } \\
\text { Coefficient }(k)\end{array}$} & \multicolumn{2}{|c|}{ Self-Confidence } & \multirow{2}{*}{ Professional Position } & \multirow{2}{*}{ Qualifications } & \multirow{2}{*}{$\begin{array}{l}\text { Years of } \\
\text { Practice }\end{array}$} \\
\hline & & Q6 & Q7 & & & \\
\hline 4 & 0.080 & 0.83 & 5.29 & Researcher & $\begin{array}{l}\text { Doctoral degree; Associated } \\
\text { Certified Coach }\end{array}$ & $5-9$ \\
\hline 15 & 0.079 & 1.00 & 10.0 & $\begin{array}{l}\text { Executive coach; } \\
\text { Researcher }\end{array}$ & $\begin{array}{c}\text { Doctoral degree; } \\
\text { Professional Certified } \\
\text { Coach }\end{array}$ & $10-14$ \\
\hline 2 & 0.073 & 0.50 & 7.43 & $\begin{array}{l}\text { Executive coach; } \\
\text { Researcher }\end{array}$ & $\begin{array}{c}\text { Doctoral degree; } \\
\text { Professional Certified } \\
\text { Coach }\end{array}$ & 15 and more \\
\hline 9 & 0.071 & 0.83 & 9.43 & $\begin{array}{l}\text { Executive coach; } \\
\text { Consultant }\end{array}$ & $\begin{array}{l}\text { Master degree; Professional } \\
\text { Certified Coach }\end{array}$ & $5-9$ \\
\hline 7 & 0.066 & 0.50 & 7.86 & Consultant & Associated Certified Coach & $3-4$ \\
\hline 3 & 0.065 & 0.67 & 6.57 & Manager & Doctoral degree & $10-14$ \\
\hline 13 & 0.064 & 0.83 & 8.57 & Other & $\begin{array}{c}\text { Master degree; } \\
\text { Associated Certified Coach }\end{array}$ & $5-9$ \\
\hline 10 & 0.062 & 0.83 & 8.43 & Executive coach & $\begin{array}{l}\text { Master degree; Professional } \\
\text { Certified Coach }\end{array}$ & $5-9$ \\
\hline 5 & 0.061 & 0.83 & 7.43 & Executive coach & $\begin{array}{l}\text { Master degree; Associated } \\
\text { Certified Coach }\end{array}$ & $3-4$ \\
\hline
\end{tabular}

Table 5. Consolidated results of the expert opinion survey.

\begin{tabular}{cccccccc}
\hline Stages & $\begin{array}{c}\text { Individual } \\
\text { Coaching }\end{array}$ & $\begin{array}{c}\text { Team } \\
\text { Coaching }\end{array}$ & $\begin{array}{c}\text { Executive } \\
\text { Coaching }\end{array}$ & $\begin{array}{c}\text { Entrepreneurial } \\
\text { Coaching }\end{array}$ & $\begin{array}{c}\text { Managerial } \\
\text { Coaching }\end{array}$ & $\begin{array}{c}\text { Coaching for } \\
\text { Innovation }\end{array}$ & $\begin{array}{c}\text { Career } \\
\text { Coaching }\end{array}$ \\
\hline Birth & 1.88 & 2.27 & 2.47 & 3.00 & 1.96 & 2.48 & 0.70 \\
Growth & 2.35 & 2.80 & 2.93 & 2.06 & 2.53 & 2.05 & 1.23 \\
Maturity & 2.58 & 2.60 & 2.94 & 1.68 & 2.85 & 2.33 & 1.87 \\
Revival & 2.73 & 2.60 & 2.73 & 1.88 & 2.72 & 2.32 & 1.89 \\
Decline & 2.33 & 2.27 & 2.60 & 2.49 & 2.25 & 2.67 & 1.41 \\
\hline
\end{tabular}

The findings of the expert opinion survey led to the creation of the model, which displays relationships between the appropriate forms and types of coaching interaction and organizational life cycle stages (see Figure 3).

By analyzing this model, it is possible to conclude that preferred forms and types of coaching vary throughout the life cycle. Two sets of coaching varieties are distinguished. The experts consider that entrepreneurial coaching, executive coaching, and coaching for innovation are more relevant to the Birth and the Decline stages, while executive coaching, managerial coaching, and team coaching are more appropriate to the Growth, the Maturity, and the Revival stages.

Executive coaching holds a special place among other forms and types of coaching. The experts identified executive coaching as having a higher priority throughout the entire organizational life cycle. The evidence of this fact can be found in the literature. The scholars [18-20,24] highlight the role of the leaders at each stage of the organizational life cycle. Greiner [24] emphasizes that even at the Birth stage when a key concern of the founders is mostly on entrepreneurial activities to design and market a new product, leadership activities should not be neglected. Grant's study [44] proves that executive 
coaching can facilitate the development of leaders to improve their leadership capability. Leadership skills are essential when the volume of sales increases and the organization grows. By positioning the executive coaching at the top of the most relevant types of coaching at the stages of growth, experts demonstrated complete agreement with the literature regarding the high level of appropriateness of the use of executive coaching at the Growth, the Maturity, and the Revival stages.

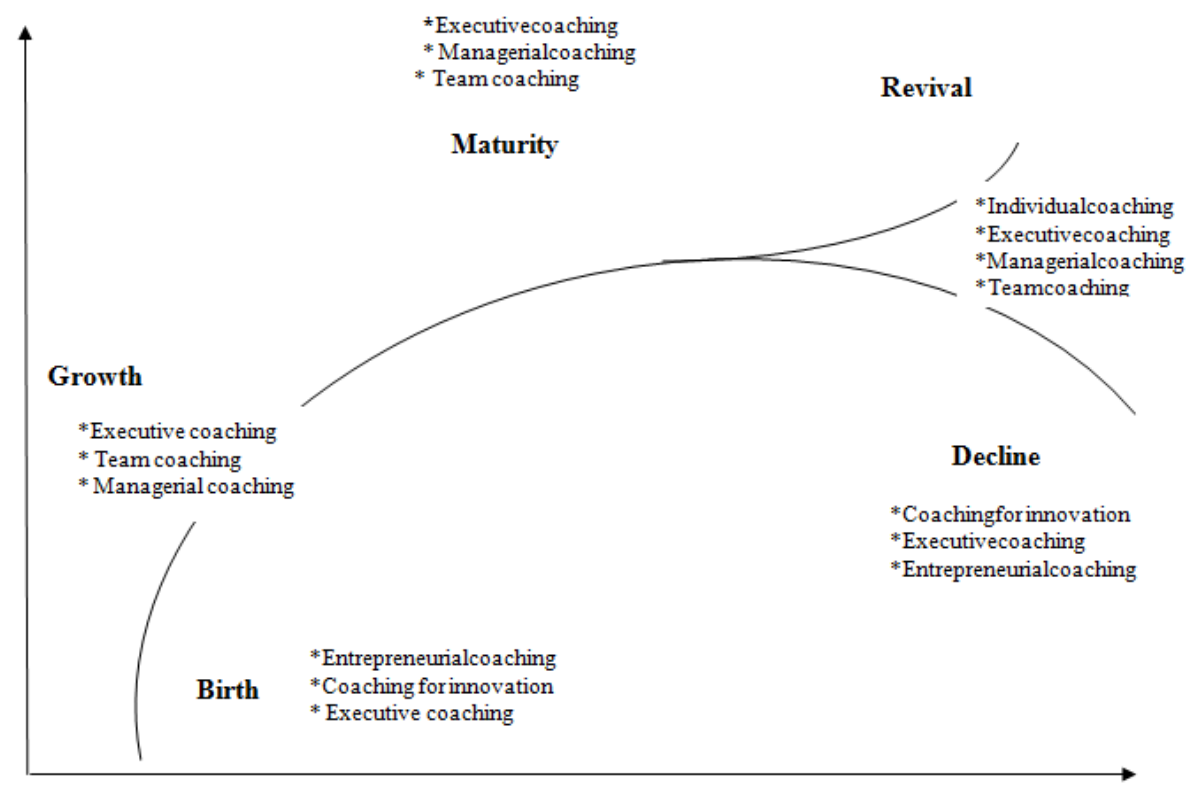

Figure 3. The open innovation model of coaching interaction throughout the organizational life cycle.

Considering the experts' evaluation of the appropriateness of the use of the forms and types of coaching at the Growth, the Maturity, and the Revival stages, it can be noted that experts identify the same set of coaching varieties for these three stages. The literature can explain this fact as follows. Traditionally, the Growth and the Revival stage are considered as the stages of growth. During the Maturity stage, the growth slows down and there comes the period of stability or even stagnation [19]. However, an organization is continuing the growth also during the Maturity stage [25]. Experts' choice demonstrates the agreement between experts' opinion and the literature regarding the feasibility of the executive coaching, managerial coaching, and team coaching to maintain and reinforce the sustainable growth.

In spite of the fact that a set of variants of coaching for the Growth, the Maturity, and the Revival stages is similar, the order of the coaching forms and types differs. Experts placed the team coaching on the second rating position for the Growth stage. Team approach to management during the Growth stage is of special significance, since teamwork enables the leaders and management to avoid excessively bold decisions, which reasonably were encouraged during the Birth stage [19].

The Birth and the Decline stages also deserve attention. The experts identify that entrepreneurial coaching, executive coaching, and coaching for innovation are most relevant to the use at the Birth and the Decline stages. The experts position the entrepreneurial coaching at the first place at the Birth stage. This result is in line with the scholar's view. Audet and Couteret [41] argue that the entrepreneurial coaching might reinforce the development of entrepreneurial skills, including creative thinking, risk taking, flexibility, and recognizing opportunities. By the survey results, entrepreneurial coaching is also relevant for use during the Decline stage.

In spite of the failure in the performance at the Decline stage, an organization still has chances to recover. Coaching for innovation is considered as the most appropriate type during this stage. Innovations play a crucial role in the organization's realignment [20]. Coaching for innovation supports an organization to develop its innovation potential and promotes innovative culture. 
The model has a deep relation with open innovation at organizational levelas a new open innovation of coaching method in connection between the coaching technology as external ideas and valuable organizational outcomes. The external flow of knowledge in the form of a new approach to coaching delivery accelerates the internal flows and internal innovation. The new coaching technologies are closely linked to the valuable organizational outcomes and thereby contribute to the sustainable development of organizations. The open innovation model of coaching interaction could leverage more internal ideas and facilitate a number of activities to capture greater value through the improvement of existing products or introduction of the new offering in the market. Additional practical value of the model in terms of its usefulness for sustainable development of organizations is ensured through the allocation of the appropriate forms and types of coaching in the context of the organizational life cycle.

\section{Conclusions}

The study explores the impact of coaching interaction on organizational development strengthen sustainable performance. The article introduces the model of the coaching interaction, which comprises the forms and types of coaching that are most appropriate for each stage of the organizational life cycle.

The model has been drawn up based on the results of expert opinion survey. The questionnaire for expert opinion survey is developed based on the literature review on the driving forces for sustainable performance of organization and the features of coaching that may accelerate these drivers. To ensure validity, three different methods were used to determine the competence of the experts. These methods include the competence coefficients $(k)$, the self-confidence evaluation, and the documented method.

The analysis of the experts' responses enables extracting both the most valuable types of coaching under each stage of organizational life cycle and the most valuable type of coaching across all the stages of organizational life cycle.

The developed model has a high practical business value. It allows for organizations to choose the optimal way of coaching delivery at any stage of organizational development. This model is particularly valuable for the coaching support programs. The model is recommended to use during the preliminary stage of the program to establish the consistency between the organization's life cycle stage and the appropriate coaching interaction.

Author Contributions: Conceptualization, A.R. and N.L.; Investigation, A.R.; Methodology, A.R. and N.L.; Supervision, N.L.; Writing-Original Draft, A.R. All authors read and approved the final manuscript.

Funding: This research was funded by the Department of Corporate Finance and Economics, Riga Technical University, Latvia. The APC was funded by the Department of Corporate Finance and Economics, Riga Technical University, Latvia.

Acknowledgments: The paper has been elaborated within the project 5.2.2 "The Development of Innovation and Entrepreneurship in Latvia in Compliance with the Smart Specialization Strategy" of the National Research Program 5.2 "Economic Transformation, Smart Growth, Governance and Legal Framework for the State and Society for Sustainable Development-A New Approach to the Creation of a Sustainable Learning Community (EKOSOC-LV)".

Conflicts of Interest: The authors declare no conflict of interest.

\section{Appendix A}

Expert opinion questionnaire. Part 2. Evaluation of the level of competence (questions 6-10).

6. Please rate the level of your theoretical knowledge, practical experience and capacity to foresee logical progression.

\begin{tabular}{cccc}
\hline & High (1) & Medium (0.5) & Low (0) \\
\hline Theoretical Knowledge & & & \\
Practical Experience & & & \\
Capacity to Foresee Logical Progression & & & \\
\hline
\end{tabular}


7. Please rate the level of your awareness for particular coaching types. "10" corresponds to "perfect awareness" and " 0 " corresponds to "absolute unfamiliarity".

\begin{tabular}{llllllllllll}
\hline & 10 & $\mathbf{9}$ & $\mathbf{8}$ & $\mathbf{7}$ & $\mathbf{6}$ & $\mathbf{5}$ & $\mathbf{4}$ & $\mathbf{3}$ & $\mathbf{2}$ & $\mathbf{1}$ & $\mathbf{0}$ \\
\hline & & & & & \\
Individual Coaching & & & & & & & & & & & \\
Team Coaching & & & & & & & & & & & \\
Executive Coaching & & & & & & & & & & & \\
Entrepreneurial Coaching & & & & & & & & & & \\
Managerial Coaching & & & & & & & & & & \\
Coaching for Innovation & & & & & & & & & & \\
$\quad$ Career Coaching & & & & & & & & & & \\
\hline
\end{tabular}

8. Please define your professional position. If more than one answer is relevant, select all that apply.

\begin{tabular}{c}
\hline Executive Coach \\
Consultant \\
Researcher \\
Head of the Organization \\
Manager \\
HR Specialist \\
Other (Please Specify) \\
\hline
\end{tabular}

9. Please indicate your qualifications. If more than one answer is relevant, select all that apply.

\begin{tabular}{c}
\hline Doctoral Degree \\
Master Degree \\
MCC (Master Certified Coach) \\
PCC (Professional Certified Coach) \\
ACC (Associated Certified Coach) \\
Other (Please Specify) \\
\hline
\end{tabular}

10. How long have you been practicing coaching? Please tick the answer.

\begin{tabular}{c}
\hline $3-4$ Years \\
$5-9$ Years \\
10-14 Years \\
15 Years and More \\
\hline
\end{tabular}

\section{References}

1. Yun, J.J. How do we conquer the growth limits of capitalism? Schumpeterian dynamics of open innovation. J. Open Innov. Technol. Mark. Complex. 2015, 1, 17. [CrossRef]

2. Yun, J.J.; Won, D.; Park, K. Dynamics from open innovation to evolutionary change. J. Open Innov. Technol. Mark. Complex. 2016, 2, 7. [CrossRef]

3. Chesbrough, H. Open Innovation: A New Paradigm for Understanding Industrial Innovation. In Open Innovation: Researching A New Paradigm, 1st ed.; Oxford University Press: Oxford, UK, 2006; pp. 1-12.

4. Vanhaverbeke, W.; Chesbrough, H.A. Classification of Open Innovation and Open Business Models. In New Frontiers in Open Innovation, 1st ed.; Oxford University Press: Oxford, UK, 2014; pp. 50-68. 
5. Dobrovolskienè, N.; Tamošiūnienè, R. An index to measure sustainability of a business project in the construction industry: Lithuanian case. Sustainabillity 2016, 8, 14. [CrossRef]

6. World Commision on Environement and Development. Our Common Future, 1st ed.; Oxford University Press: Oxford, UK, 1987; p. 400.

7. Robert, K.W.; Parris, T.M.; Leiserowitz, A.A. What is sustainable development? goals, indicators, values, and practice. Environ. Sci. Policy Sustain. Dev. 2005, 47, 8-21. [CrossRef]

8. Linnenluecke, M.K.; Griffiths, A. corporate sustainability and organizational culture. J. World Bus. 2010, 45, 357-366. [CrossRef]

9. Dyllick, T.; Hockerts, K. Beyond the business case for corporate sustainability. Bus. Strategy Environ. 2002, 11, 130-141. [CrossRef]

10. Stanciu, A.C.; Constandache, M.; Condrea, E. Concerns about the sustainable performance of firm in the context of quality management systems implementation. Procedia Soc. Behav. Sci. 2014, 131, 340-344. [CrossRef]

11. Dobrovolskiene, N.; Tamošiuniene, R. Sustainability-Oriented financial resource allocation in a project portfolio through multi-criteria decision-making. Sustainability 2016, 8, 485. [CrossRef]

12. Kocmanová, A.; PavlákováDočekalová, M.; Škapa, S.; Smolíková, L. Measuring corporate sustainability and environmental, social, and corporate governance value added. Sustainability 2016, 8, 945. [CrossRef]

13. Dočekalová, M.P.; Kocmanová, A. Comparison of sustainable environmental, social and corporate governance value added models for investors decision making. Sustainability 2018, 10, 649. [CrossRef]

14. Woo, H.R. Exploratory study examining the joint impacts of mentoring and managerial coaching on organizational commitment. Sustainability 2017, 9, 181. [CrossRef]

15. Bozer, G.; Sarros, J.C.; Santora, J.C. The role of coachee characteristics in executive coaching for effective sustainability. J. Manag. Dev. 2013, 32, 277-294. [CrossRef]

16. Vidal-Salazar, M.D.; Ferrón-Vílchez, V.; Cordón-Pozo, E. Coaching: An effective practice for business competitiveness. Compet. Rev. 2012, 22, 423-433. [CrossRef]

17. Hackman, J.R.; Wageman, R. A Theory of team coaching. Acad. Manag. Rev. 2005, 30, 269-287. [CrossRef]

18. Kazanjian, R.K.; Drazin, R. A stage-contingent model of design and growth for technology based new ventures. J. Bus. Ventur. 1990, 5, 137-150. [CrossRef]

19. Miller, D.; Friesen, P.H. A Longitudinal Study of the Corporate Life. Manag. Sci. 1984, 30, 1161-1183. [CrossRef]

20. Hanks, S.H. The organization life cycle: Integrating content and process. J. Small Bus. Strategy 1990, 1, 1-12.

21. Reid, S.E.; Brentani, U. Market Vision and Market Visioning Competence: Impact on Early Performance for radically new, high-tech products. J. Prod. Innov. Manag. 2010, 27, 500-518. [CrossRef]

22. Kim, J.; Jung, S. Study on CEO characteristics for management of public art performance centers. J. Open Innov. Technol. Mark. Complex. 2015, 1, 5. [CrossRef]

23. Lester, D.L.; Parnell, J.A.; Carraher, S. Organizational life cycle: A Five-Stage Empirical Scale. Int. J. Organ. Anal. 2003, 11, 339-354. [CrossRef]

24. Greiner, L. Evolution and revolution as organizations grow-Harvard business review. Harv. Bus. Rev. 1998, 76, 55-68. [PubMed]

25. Scott, M.; Bruce, R. Five Stages of growth in small business. Long Range Plan. 1987, 20, 45-52. [CrossRef]

26. Chukhray, A.; Novakivskii, I. Life Cycle Business Modelling. Econtechmod 2015, 4, 17-24.

27. Ionescu, G.; Negrusa, A. The Study about Organizational Life Cycle Models. Rev. Int. Comp. Manag. 2007, 8, 5-17.

28. Rutherford, M.W.; Buller, P.F.; McMullen, P.R. Human resource management problems over the life cycle of small to medium-sized firms. Hum. Resour. Manag. 2003, 42, 321-335. [CrossRef]

29. Ciemleja, G.; Lace, N. The model of sustainable performing of SMEs in context of company's life cycle. In Proceedings of the 15th World Multi-Conference on Systemics, Cybernetics and Informatics, Orlando, FL, USA, 19-22 July 2011.

30. Duobiene, J. Corporate entrepreneurship in organisational life-cycle. Econ. Manag. 2013, 18, 584-595. [CrossRef]

31. Yusr, M.M. Innovation capability and its role in enhancing the relationship between tqm practices and innovation performance. J. Open Innov. Technol. Mark. Complex. 2016, 2, 6. [CrossRef]

32. Lee, S.H.; Jung, K.; Workman, J.E. Exploring neglected aspects of innovation function: Public motivation and non-pecuniary values. Sci. Technol. Soc. 2016, 21, 435-464. [CrossRef] 
33. Cox, E.; Bachkirova, T.; Clutterbuck, D. Theoretical traditions and coaching genres. Adv. Dev. Hum. Resour. 2014, 16, 139-160. [CrossRef]

34. Popper, M.; Lipshitz, R. Coaching on leadership. Leadersh. Organ. Dev. J. 1992, 13, 15-18. [CrossRef]

35. Burdett, J.O. Forty things every manager should know about coaching. J. Manag. Dev. 1998, 17, $142-152$. [CrossRef]

36. Grant, A.M.; Cavanagh, M.J. Toward a profession of coaching: Sixty-five years of progress and challenges for the Future. Int. J. Evid. Based Coach. Mentor. 2004, 2, 1-16.

37. Stober, D.R. Making It stick: Coaching as a tool for organizational change. Coach. Int. J. Theory Res. Pract. 2008, 1, 71-80. [CrossRef]

38. Trenner, L. Business coaching for information professionals. Bus. Inf. Rev. 2013, 30, 27-34. [CrossRef]

39. Rosha, A.; Lace, N. The scope of coaching in the context of organizational change. J. Open Innov. Technol. Mark. Complex. 2016, 2. [CrossRef]

40. Rousseau, V.; Aubé, C.; Tremblay, S. Team coaching and innovation in work teams. Leadersh. Organ. Dev. J. 2013, 34, 344-364. [CrossRef]

41. Audet, J.; Couteret, P. Coaching the entrepreneur: features and success factors. J. Small Bus. Enterp. Dev. 2012, 19, 515-531. [CrossRef]

42. Duff, A.J. Performance management coaching: Servant leadership and gender implications. Leadersh. Organ. Dev. J. 2013, 34, 204-221. [CrossRef]

43. Feldman, D.C.; Lankau, M.J. Executive coaching: A review and agenda for future research. J. Manag. 2005, 31, 829-848. [CrossRef]

44. Grant, A.M. The efficacy of executive coaching in times of organisational change. J. Chang. Manag. 2014, 14, 258-280. [CrossRef]

45. Joo, B.K. executive coaching: A conceptual framework from an integrative review of practice and research. Hum. Resour. Dev. Rev. 2005, 4, 462-488. [CrossRef]

46. Bozer, G.; Sarros, J.C. Examining the effectiveness of executive coaching on coachees performance in the israeli context. Int. J. Evid. Based Coach. Mentor. 2012, 10, 14-32.

47. De Meuse, K.P.; Dai, G.; Lee, R.J. Evaluating the effectiveness of executive coaching: Beyond ROI? Coach. Int. J. Theor. Res. Pract. 2009, 2, 117-134. [CrossRef]

48. Ratiu, L.; David, O.A.; Baban, A. Developing managerial skills through coaching: Efficacy of a cognitive-behavioral coaching program. J. Ration. Emotive Cogn. Behav. Ther. 2016, 34, 244-266. [CrossRef]

49. Anderson, V. A Trojan horse? The implications of managerial coaching for leadership theory. Hum. Resour. Dev. Int. 2013, 16, 251-266. [CrossRef]

50. Ellinger, A.D.; Ellinger, A.E.; Bachrach, D.G.; Wang, Y.L.; Elmadag Bas, A.B. Organizational investments in social capital, managerial coaching, and employee work-related performance. Manag. Learn. 2011, 42, 67-85. [CrossRef]

51. Hollywood, K.G.; Blaaess, D.A.; Santin, C. Holistic mentoring and coaching to sustain organizational change and innovation. Creighton J. Interdiscip. Leadersh. 2016, 2, 32-46. [CrossRef]

52. Benini, A.; Chataigner, P.; Noumri, N.; Parham, N.; Sweeney, J.; Tax, L. Expert Judgment-The Use of Expert Judgment in Humanitarian Analysis-Theory, Methods and Applications. Available online: https:/ / reliefweb.int/sites/reliefweb.int/files/resources/acaps_expert_judgment_-_full_study_ august_2017.pdf (accessed on 27 September 2018).

53. Pavlov, A.; Sokolov, B. Methods for Processing Expert Information; GUAP, SPb: Saint Petersburg, Russia, 2005; p. 42. (In Russian)

(C) 2018 by the authors. Licensee MDPI, Basel, Switzerland. This article is an open access article distributed under the terms and conditions of the Creative Commons Attribution (CC BY) license (http:// creativecommons.org/licenses/by/4.0/). 